\title{
The Study about the Internal Financial Control of Power Enterprises under the ERP Environment
}

\author{
Yijing Liang \\ School of Economics and Management, North China Electric Power University; Baoding, Hebei \\ 071000, China; \\ 349041396@qq.com
}

Keywords: The Electric Power Enterprise, ERP, Internal Financial Control.

\begin{abstract}
Under the current situation in which modern information technology is developing rapidly, ERP system that can improve the efficiency and benefits of the enterprise management has been widely used. ERP system creates good conditions for the internal financial control of the enterprise, but also brings new risks. Combining with the application of ERP system in electric power enterprise, this paper is to discuss the role of ERP in the internal financial control of the electric power enterprise, and to analyze the main problem in the implementation of ERP in the electric power enterprise system, which aims to provide a solution to the improvement of internal financial control of the electric power enterprise under the ERP environment.
\end{abstract}

\section{Introduction}

ERP (Enterprise Resource Planning) is an Enterprise Resource Planning, it is the product of accounting informationization development trend, the accounting data information, information can be automatically transfer between each module, and on the basis of computer technology, the Enterprise Resource integration, the procurement, production, costs, inventory, distribution, transportation, finance, human resources Planning to be managed and controlled, aimed at to optimize Resource configuration, improve the management efficiency and benefits.ERP is not only a set of software system, but also a kind of advanced management concept.

\section{The impact of ERP which in the financial control of power enterprises}

\subsection{Enhance the level of financial management in power enterprises.}

The ERP system broke through the problem that certification procedure of traditional financial management mode is too complex and its workload is very heavy and promoted the upgrade of financial management from the type of business counting to the type of management. The financial management system integrates with other modules dynamically and every module is highly integrated and coupled dynamically. The financial staff can import or read the information of other modules timely and correctly form financial management system, so that the work of financial management could be elaborate and standard. Moreover, the ERP can promote power enterprises to attach more importance to those management activities such as projecting, forecasting and analyzing. It can change the traditional management philosophy and methods and intensify the functions of financial management and decision-making ability to improve the professional quality of financial staff constantly and make the financial management more scientific meticulous, standard and effective.

\subsection{Push forward the power enterprises to realize the comprehensive budget management.}

The comprehensive budget management under the ERP system is based on system integration and information sharing. It deduced from business budget to the financial budget and transmit the financial budget to lower levels to control the budget and make the establishment, approval, execution, appraisal and evaluation and control of budget band together. So, the generalization and closed-management can be realized comprehensively. The ERP system offers guarantee the company overall budget targets and improves the reliability of variation analysis and veracity of budgeting. 
The system strengthens the balanced ability of producing and the cost control function and put the responsibility into practice in every functional department. It promotes the internal financial control of power enterprises with the principle of scientificity, importance and compulsory.

\section{The subject matter that occurred in the internal financial control of power enterprises under the ERP environment.}

\subsection{The employees' insufficient understanding, the back sense and limited ability.}

The ERP is a kind of international advanced management idea and method as well as the digital expression of scientific management process. So the introduction of ERP means that the enterprise should break through the original financial accounting. However, current power enterprises has never been reformed in the part of internal financial control and the management lager have never realized sufficiently the function of ERP system to finance controlling of inner enterprise. For the accounting staff which is accustomed to the traditional pattern, they would be unfamiliar with this modern information technology and be a little strenuous to use the ERP system in a short time. Meanwhile, the professional accounting works have different level in China and their overall service quality is need to be intensified. Only a few talented people can understand the financial affairs and make themselves master of information technology. This kind of situation increases the difficulty which to construct the ERP system.

\subsection{The position statement is distributed unreasonably and the functions are highly integrated.}

Under the ERP system, the overall process of accounting data is highly integrated. And in the process of popularizing and implementing the ERP system, to build a flat institution framework that lead to the equipment of financial personnel at the grass-roots level is insufficient and their work task is heavy and responsibility division is not clear. For example, the right and liabilities of programming personnel, basic data entry personnel and accounting audit personnel is not adjusted and separated timely. If the power and responsibility of system administrators is unauthorized to modify the business information and financial data will take shape. Again for instance, because the ERP system can't part off the station that concerned about document preparing, charge accounting table making and checking, a highly integrated electronic function result in the excessive concentration of responsibility. Some job functions that can't incompatible with each other are integrated into one station, and the internal hidden trouble is formed very easily.

\subsection{Some new risk issues have arisen.}

The data quality problem.

In the ERP system, the staff input the original data to original certificate, so the detail account, daily book and other accounting data can generate automatically in computer system. If original data is input incorrectly, the wrong data will be used in the system repetitively and spread and enlarged in a very fast way. In the meantime, there are some hidden problems about the preservation of the data. If the computer system is not stable enough and easily it is bring about the breakdown of system. Thus, the data would be broken or lost. And in the process of electronic data exchanges, if enterprise don't impose restrictions on access rights and let lawbreaker get into the database system to modify or delete the data. That will bring great danger to information management.

The aggravation of business process risk.

The ERP system brought a great reform to traditional processing of account information and the way to transfer it. After the input of original data it produced the other accounting data automatically. Due to the existence of database, the traditional control mode such as card account check, account-account check and account-table check have passed out of existence. Without leaving auditing clues for auditing supervision, the control function to business process has been weakened greatly. 


\section{The strengthen measures of power enterprises internal financial control in ERP system.}

\subsection{Improve the comprehensive quality of financial staff in power enterprises and realize the transformation of functions and roles.}

The power enterprises should treat the education about internal financial control as a very important part in breeding enterprise culture. The application training which is concerned with ERP management technology and knowledge on financial area should be carried out and the consciousness of financial management should be strengthen. Also, the understanding of financial staff to the ERP system should be deepened and let the staffs perfect themselves in management of all kinds of business under the information system. Achieve the transform from traditional manual accounting to accounting information system applications while improving the position of internal financial control in management process. The level of accounting information professional team not only make a difference on the level of financial accounting work but also be related to improvement of power enterprises management level and the realization of strategic goals. The ability of financial prediction, business communication, management control and information technology use should be reinforced while guaranteeing the accounting knowledge application ability .At the same time, encourage financial staffs to learn about and have subject study on this system, and invite experts in tax administration, audit, management and computer application to open some lectures. What's more, carry out the check work at regular intervals and foster new type of management talents.

\subsection{Intensify the accrual management of station and perfect the organization structure and dispatching of rights and obligations.}

First of all, power enterprises should outfit accounting personnel reasonably, strengthen the assignment of responsibility, set up the system of financial personnel communication, optimize the financial position construction and realize the optimal configuration of financial resources according to business volume and requirements of financial internal control. Second, in order to break through the disadvantages of functions of highly integrated, the enterprises should implement authentication, process control of application, process control of budget management and check the executive condition of internal financial control. Operating authorization should be set according to internal control requirements, in compatible stations should be separated strictly and authorize reasonably. All the stations should restrict and supervise each other. In addition, the organization structure should be further adjusted. The flattening organization structure of power enterprises should be improved to adapt the managing requirement of ERP system and make clear the ownership management of the cost centers and operating departments and the functional authorities of finance.

\subsection{Set up the safety protection system for accounting information and rebuild the business process in ERP system}

On the one hand, accounting information system should be check at regular internals and maintenance contents should be recorded in time. The quality and reason of maintenance should be analyzed and a series of information maintenance of accounting information should be set up and inspection and maintenance should be taken according to standard procedure and matters need attention at regular intervals. On the other hands, data information should be protected and prevent leaking the data. The network security settings of enterprise should be improved and complete the work of computer virus defense. In addition to this, the perfection of business process should be kept pushing forward in ERP system, and the business process should be straightened out to promote closed relationship between primary stage of business and financial information. The financial flow, business flow and capital flow should be mixed together comprehensively. Strengthen the publicity and connection of financial management and push forward the expansion of ERP system in power enterprises basic level. Ensure the data transmit according flow path and realize their unify. 


\section{Summary}

With the rapid development of economy, science and technology, the application of ERP system is more and more widely, not only affects the electric power enterprise management environment and the management idea, is also changing the content and form of the electric power enterprise financial internal control. In today's information management, the electric power enterprise should set up concept, perfecting the internal control of ERP system to face the insufficient use of ERP system at this stage, and combined with the actual situation of the development of electric power enterprises, specifically looking for solutions, promote the ERP system and internal control of enterprise financial better integration, through ERP "soft science" promoting financial internal control the "hard power", promote the electric power enterprises achieve the goal of "a strong three-excellent", fully into the era of modern management.

\section{References}

[1] Qian Zhang, Yanbo Zhao. et al. Enterprise internal control risk and its solutions in ERP system. Business conditions. 2008. No. 44, p. 257.

[2] Caixia Wang.et al. The discussion to the accounting information internal control in ERP system. CE.2013.No.2, p.39-41.

[3] Lin Ma. et al. The exploration of financial internal control issue in ERP system. SGCC. 2010. No. 9, p. 98-99.

[4] Xiaomin Yang. et al. The dilemma and solutions to the integration of financial management inpower enterprises in ERP system. China’s foreign investment. 2013.No.3,p.153-152.

[5] Fagui $\mathrm{Xu}$. et al. The system construction of power enterprises internal control power enterprises in ERP system. Financial community(academic). 2009.No.6.p,147-149. 